\title{
Granisetron Hydrochloride Nasal Spray
}

National Cancer Institute

\section{Source}

National Cancer Institute. Granisetron Hydrochloride Nasal Spray. NCI Thesaurus. Code C124052.

An intranasal formulation containing the hydrochloride salt form of the indazole derivative granisetron, a selective serotonin (5-hydroxytryptamine; 5-HT) receptor antagonist, with antinauseant and antiemetic activities. Upon administration to the nostril, granisetron selectively binds to and inhibits 5-HT subtype 3 receptors (5-HT3R) located peripherally on vagus nerve terminals and centrally in the chemoreceptor trigger zone (CTZ) of the area postrema, which may result in suppression of chemotherapyinduced nausea and vomiting (CINV). 